Copyright (C) 2015 by Academic Publishing House Researcher

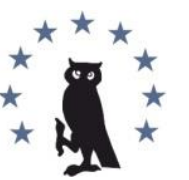

Published in the Russian Federation

European Researcher

Has been issued since 2010.

ISSN 2219-8229

E-ISSN 2224-0136

Vol. 100, Is. 11, pp. 747-758, 2015

DOI: 10.13187/er.2015.100.747

www.erjournal.ru

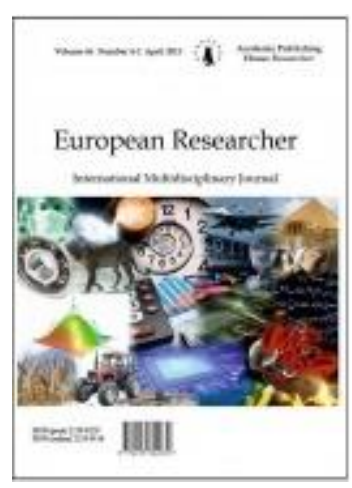

Cultural studies

Культурология

UDC 79

\title{
The Geographical Aspects of Traditional Handicrafts in Serbia
}

\author{
${ }^{1}$ Tamara Lukić \\ ${ }^{2}$ Tatjana Stojanović \\ 3 Bojan Đerčan \\ ${ }_{4}^{4}$ Milka Bubalo Živković \\ 5 Jelena Živković
}

${ }^{1}$ University of Novi Sad, Faculty of Sciences, Novi Sad, Serbia

Associate professor, corresponding author

E-mail: snstamara@yahoo.com

${ }^{2}$ Veljko Petrović' High School, Sombor, Serbia

PhD candidate

3 University of Novi Sad, Faculty of Sciences, Novi Sad, Serbia

Assistant professor

4 University of Novi Sad, Faculty of Sciences, Novi Sad, Serbia

Associate professor

5 University of Nis, Faculty of Science and Mathematics, Nis, Serbia

Assistant

\begin{abstract}
The first part of paper is dedicated to current research related to traditional handicrafts in the world. Then, traditional handicrafts are viewed from the geographical perspective. The paper analyzes the relationship between the physical and geographical characteristics, the type of handicraft and raw material base. Most of the paper is devoted to the social factors that influence the traditional handicrafts. The paper lists the forms of support to preserve traditional handicrafts that goes in favor of their sustainability. The paper shows examples of work on the preservation of traditional crafts in Serbia. The paper describes the possibilities of placing items produced by traditional handicrafts. By displaying manifestations, paper illustrates some traditional handicrafts. In addition, the paper discusses the actual problems of the traditional handicrafts. The significance of the paper is that it is written record of traditional handicrafts in Serbia at the beginning of the 21st century, because they are no longer subject to monitoring of official statistics. The aim of this paper is to motivate the youth and the unemployed to look for themselves in originality, excellence and financial justification of working in traditional handicrafts. On that way, traditionally handicrafts could to maintain their viability.
\end{abstract}

Keywords: handicrafts, tradition, Serbia, manifestations, sustainability. 


\section{Introduction}

For decades, handicrafts have disappeared due to mechanical production and traditional production of certain items is almost forgotten. Traditional craft means creating unique products and services, which are based on traditional knowledge and technologies, the use of natural materials in the production process, using simple tools. In categorization of crafts they are labeled as traditional crafts, which include traditional manufacturing, cooking of traditional dishes and building activity. Regulation on classifications of professions that are considered as old and artistic crafts (Sl. glasnik RS, 2012) clearly outlines the types of crafts. Among all, the most common are pottery, farriery, cooper, draper, clothier, candy making, traditional footwear craft, weaving, tanning (e-Kapija, 2013). Traditional craftsmanship reflects the conditions and centuries-long traditions of folk life in the countryside and the city.

According to the census, craftsmanship as a statistical category of activities was followed by the end of the 2oth century. In the following years, there were data in the form of internal documentation on the number of enterprises, institutions and other legal entities in the category of craft and personal services. In the last two censuses, data on crafts have disappeared completely as a category because they were treated in the context of other, related or less related categories. The idea for this work was initiated by information from the media, which more often show different stories about traditional crafts. The significance of the research is that it will give written evidence and represent contribution to themes of traditional crafts at the beginning of the 21st century, about which there is neither significant literature, nor integrated geographic approach. The task of this paper is to examine whether traditional craftsmanship in Serbia can be sustainable. The significance of this paper is to show the geographical aspects, which can be put in the function of sustainability.

\section{Methods}

Certain information about traditional crafts was obtained through interviews. Qualitative research is done on small samples up to 100 respondents, although there are no rules about the sample size in qualitative research. The sample size depends on what one wants to know, what is the purpose of research, what is basic, what can be useful and what can realistically be done within the available time and resources (Patton, 1990). Qualitative research was conducted by the method of in-depth interviews with 87 respondents, because it gives 'broader picture' of the research subject. Of the total number of respondents, most were women (80.5\%). Among them there are very few young people. Respondents generally live in rural areas (78.2\%) and usually have completed high school (74.7\%) (Table). Semi-structured interview had approximately 30 questions. Responses reveal important information about the current situation, the purchase of raw materials, the sale of products, the social support, the problems and the like. Respondents are the people who are engaged in traditional crafts and the other from their close environment. Respondents were found at different events in the Republic of Serbia. The big problem was that many people were not ready to participate in the study. When selecting respondents it was sought that their activities are in different types of traditional crafts. In addition, in this paper it was used different literature, the Internet and cartographic sources. Data processing used analysis and comparison. Based on data, we came to conclusions by systematization and deduction.

Table 1: Socio-demographic characteristics of the respondents, Source: Survey

\begin{tabular}{|l|l|r|r|r|}
\hline \multicolumn{2}{|l|}{ Sociodemographic features } & \multicolumn{3}{c|}{$\%$} \\
\hline Gender & \multicolumn{1}{|c|}{ total } & \multicolumn{1}{c|}{ f } \\
\hline \multirow{3}{*}{ Age } & $20-39$ & 13.8 & 2.3 & 11.5 \\
\cline { 2 - 5 } & $40-59$ & 28.7 & 4.6 & 24.1 \\
\cline { 2 - 5 } & $60+$ & 57.4 & 12.6 & 44.8 \\
\hline \multirow{3}{*}{ Education } & Primary school & 9.2 & 2.3 & 6.9 \\
\cline { 2 - 6 } & Secondary school & 74.7 & 13.8 & 60.9 \\
\cline { 2 - 6 } & Faculty & 16.1 & 3.5 & 12.6 \\
\hline \multirow{3}{*}{ Settlement } & Urban & 21.8 & 5.7 & 16.1 \\
\cline { 2 - 6 } & Rural & 78.2 & 13.8 & 64.4 \\
\hline
\end{tabular}




\begin{tabular}{|l|l|r|r|r|}
\hline \multirow{2}{*}{ Occupation } & Basic & 86.2 & 14.9 & 71.3 \\
\cline { 2 - 5 } & Additional & 13.8 & 4.6 & 9.2 \\
\hline
\end{tabular}

Previous research

In Serbia, the traditional crafts are mentioned from a historical perspective (Miljković Katić, 2013) in terms of the description of the products, museum collections or the production process (Dušković, 2009). World literature is devoted to specific crafts (Staniland, 1991; Bilgin et al, 2011; Jevremović, 2011; Dhupelia-Mesthrie, 2012; Sezeva, 2013). Clark (2013) published her doctoral thesis which is dedicated to the production of books, in terms of analysis of space, materials and dynamics of communication in the so-called textbook art. Petkovski (1992) speaks about streets dedicated to old crafts. Pal (2011) writes about the geography of urban footwear industry in West Bengal, India. However, there are other works which observe traditional crafts in various ways. Thus, some studies explored the craftsmanship from an anthropological point (Chamorro, 2007; Giordano 2007), the other from a social (Hailwood, 2011), and from an environmental perspective (Dean et al, 2000, Sanchez-Medina et al 2010), while there are studies investigating how much hazards can affect some of its species (Colombini et al, 2012). Đurkovic (2011) admires the vitality of ethnological heritage in Serbia, where in addition to the old crafts he classify dancing, singing, cooking, fashion and souvenirs. He noted that those in a chaotic, unplanned and outlaw way survive despite the generally hostile attitude of the state and a large part of the elite towards them.

Crafts are linked to different geographic characteristics. Certain crafts symbolize certain ethnic groups (Nason, 1984; Zhiyi, 2014; Coates et al, 2015) or they are performed by people of the same sex (Little, 2014).

Most of the studies highlight the importance of traditional crafts for small business (SánchezMedina et al, 2015), mostly in underdeveloped or less developed countries. A number of studies deal with sustainable craftsmanship (Mustafa, 2011). Many countries on different continents strongly rely on craftsmanship, both in terms of increasing employment and in terms of environmental sustainability of this activity, but also in economic terms (Avais et al, 2014; Mir \& Bhushan, 2014).

As research has shown that craftsmanship is an attractive activity that enriches the tourist offer of an area and can bring significant incomes, for example, through souvenirs (Holder, 1989; Parnwell et al, 1993; Christie \& Cromption, 2001). For others, it is the agro-tourism which supports traditional craftsmanship (Kiran et al, 2014). Dutton (1983) discusses the importance of traditional crafts for rural development in general. Some scientific papers deal with the problems of locating facilities for the distribution of traditional crafts, for the best economic effect (Karami et al, 2013). Due to affirmative political will, there are protective mechanisms for traditional crafts (Zhiyi, 2014). In Croatia, in addition to other women's activities, production of decorative objects is a way for activation, motivation and involvement in the labor market, which is also supported by the resources of the IPA program (HZZZ, 2011). In 2009, traditional crafts in Serbia have been placed, as a separate segment, under the auspices of the Ministry of Commerce, which has done a very good basic web presentation and an initial exhibition with valuable catalog in cooperation with Ethnographic Museum in Belgrade. It has been prepared and passed a legislation that provides for entrepreneurs who operate in this field of creativity are exempt from paying value added tax (Đurković, 2011). In the literature, there are numerous examples of how traditional crafts can be placed in other functions, for example Cogollor et al. (2012) speak about their applicability in cognitive rehabilitation.

In literature instead of the term traditional crafts it can found expression traditional craftsmanship or folk fine arts (Novaković 2004; Šestan, 2006). Specificity of the geographical position of Serbia, and its openness to diverse cultural influences determined the ways of artistic expression in the traditional rural culture, i.e. what it is implied by the term of folk fine arts.

\section{Results and Discussions}

Natural predispositions for traditional craftsmanship

It is accepted attitude that the nature and culture are complementary categories. They can not be considered separately. The cultural identity of a community is connected with the natural environment in which is developed (Hadžić, 2005). Traditional craftsmanship is part of the 
cultural identity and is often exhibited in museums in the open (Krstović, 2012). Raw materials (rocks, water, land, plants, animals) which are used in traditional craftsmanship mainly come from the local community and their characteristics are determined by geographic characteristics in which they are located. Geological structure includes types of rocks in a certain area. Rocks were used for the construction and decoration of residential buildings, gravestones, but also for mills, shadoof, various metal processing. According to the Regulation on classification of professions that are considered as old crafts (Sl. glasnik RS, 2012), grinding, stone-paving and stone-cutting crafts use solid volcanic and metamorphic rocks. Sedimentary rocks are used in calcination of limestone, charcoal and making of tar. These rocks are found in quarries throughout Serbia.

Wind energy had been used in Vojvodina. Contemporary mills have induced the profitability drop of windmills and dry mills, but they have a landscape and culture-historical values, so they are affirmed to some extent in terms of tourism. From the standpoint of stability and characteristics of wind rose in this part of Serbia, the construction of replicas of windmills and demonstration of their work can be economically justified.

Hydrologic characteristics induced the existence of professions such as well-digger and ferryman. Well-diggers survived in the Pannonian area. Ferryman can pose a tourist attraction. However, in 1999, during the 'Merciful Angel', people of Serbia remember how overnight ferrymen become sought and respected. There are traces of the last ferrymen on the biggest Serbian rivers, such as Ibar, Drina, Sava rivers, etc. (RTS, 2011; Gucijan, 2009; Apostolovski, 2012).

Typical soil provides raw materials for masons and potters and those who make tile stoves and firebrick. Sometimes making of a product requires several types of land, or several varieties, for example, clay. On the territory of Vojvodina, each village has at least one water area, which was created by removing the soil during the construction of settlement. Water is a consequence of the shallow phreatic aquifer, which goes to the topographic surface when its aquifer is cut. Most of the residential buildings in the north of Serbia were built using soil, the so-called 'adobe house'.

The geological structure, under the characteristic relief predispositions, induces forming characteristic types of soil and cultivating certain plant and animal species. Wood is used by carpenters and coopers. The need for real wooden barrels exists even today, as they are indispensable in viticulture and dairy. Serbia is a country which in the past did not lack forest vegetation. Marsh vegetation had versatile use. Bulrush or cattail is the main raw material used by wicker craftsman and cane by basket makers. Plant, such as, for example, sorghum, is used for brooms. Vineyards were cared by guardians of vineyard (namely pudar). Candy makers used beet sugar and honey in their crafts. The wool is used by rug makers, draper and clothier, goat hair by weavers and brush makers; leather by shoemakers, furriers, saddlers, and tallow by soap boilers etc.

The above-mentioned raw materials that are used, finished products and waste that arise in the process of making craft items, due to their natural origin, do not pollute the environment, so they serve function of sustainability from ecological point of view.

Geo-demographic impact on traditional craftsmanship

The development of industry and abandonment of traditional crafts caused that most of them have disappeared. Studies indicate gender layering based on the types of crafts (Dhamija, 1981; McLeod, 1999; Rostami Povey, 2003; HZZZ (2011). In Serbia, well-digger, guardians of vineyard, carpenters and coopers are mostly men. Among some traditional crafts, men are organizers, and women are producers. Data on geo-demographic characteristics can be obtained only in communication with those who are dealing with the old crafts. Therefore, it is necessary to organize a special research. Analysis of the literature shows the following facts. In some traditional crafts women appear unexpectedly, for example, as ferrymen (Apostolovski, 2012; Gucijan, 2009; RTS, 2011). The unfavorable age structure that was observed through interviews during field research in Serbia. It is a result of the lack of interest of young people in this industry, but also because of population aging on the national level. However, research has shown that there is a lot of 'room' for youth engagement in the form of a hobby, additional activities, self-employment and efforts to preserve cultural heritage. The majority (69.0 \%) of respondents said they have trouble to find a successor who will continue to engage in certain traditional craft. A significant proportion (58.6\%) said that it often happens that someone starts performing some traditional craft just because he/she can not find another job with minimal investment. Minimal investments in raw materials have mainly knitters, embroiderers, tailors, etc. 
Support for traditional crafts

Traditional crafts and techniques often serve as inspiration (Cvetković, 2015). Preservation of traditional crafts is important for the enrichment of the tourist offer. Čomić (2003) said that tourism contributes to the adoption of a number of measures for the preservation of traditional crafts, customs, folklore festivals and the like. Due to its needs, at least ostensibly, it keeps alive certain features of traditional culture, which would definitely disappear otherwise under the impact of mass culture and modernization, which have no need for the traditional customs and crafts.

Sustainability of traditional crafts is positively influenced by political support, various entrepreneurial initiatives and involvement of young people motivated by artistic emancipation. Political support has different forms. For example, there is state support for enterprise registration and certification. In 2013, The Ministry of Foreign and Domestic Trade of the Republic of Serbia allocated grants for the development of traditional crafts (e-Kapija, 2013). Long-term loans for the old artistic crafts are intended for business entities for which the Ministry of Economy and Regional Development of the Republic of Serbia issued a special certificate. The loans are intended for the construction, extension, reconstruction, renovation and repair of business locales i.e. manufacturing and industrial facilities, as well as for the purchase of new or used equipment, or tools from business entity, or for the purchase of permanent working capital (Erić et al, 2012).

Secretariat for Economy of the City of Belgrade has an action plan that is implemented by its institutions, through various programs such as workshop called 'Information and knowledge to the goal', Job fair and 'Belgrade Investment Days'.

In the second decade of the $21^{\text {st }}$ century, political support is visible in the area of Vojvodina, the northernmost region of the Republic of Serbia. Provincial Secretariat for Economy, Employment and Gender Equality allocate grants (subsidies) to non-governmental organizations and other nonprofit institutions for the development and rehabilitation of works that are considered as old and artistic crafts, i.e. local handicrafts. In Novi Sad, center of the Province of Vojvodina, in the old town, was formed passage old crafts (Novi Sad, 2013). In Sombor, a city located about $100 \mathrm{~km}$ northwest of the provincial center, Provincial government was provided financial support to those engaged in traditional crafts, by organizing the event 'Street of old crafts'. In the press, there are numerous examples of financial support from the municipalities, as well.

Example of international support is transparent through the project of design and preservation of traditional crafts titled 'Exploring inspirations'. It was supported by Stimulering Fund Creative Industries Fund Netherlands and had three disciplines: design of clothing, jewelry and footwear (Cvetković, 2015).

Space for artistic emancipation of young people exists through the development of souvenir program. Incomes from the sale of souvenirs speak in favor of the importance of the role of tourism on the sustainability of traditional crafts. The importance of marketing in the case of the traditional craftsmanship is extremely important. According to Dugalic (2009), the Belgrade workshop of candies and Turkish delight called 'Bosiljčić' entered the textbooks for the third grade of elementary school, and has been frequently visited by pupils. Social affirmation of traditional crafts in terms of events and organization of space devoted to them is noticeable. Most respondents (97.7\%) agreed that they very appreciate material and political support, and that any other form of support goes in favor of the promotion of traditional crafts.

The traditional craftsmanship and events

People from Serbia dealing with traditional crafts (93.1\%) say that manifestations are one of the most important forms of their struggle for survival. Aim of events is to contribute to preservation, development, and particularly presentation and evaluation of craft skills that are part of the intangible cultural heritage in the territory, and great potential for their sustainable development. At these events, in addition to exhibiting and selling products, craftsmen show traditional craft techniques and products to visitors.

The reason for the success of events on the theme of traditional crafts is in recognizing the importance of cultural heritage, which is the 'roots' for the sense of identity and belonging to both an immediate community and wider European community. Also, through the wealth of diversity built during multi-centurial contacts, influences and exchanges between peoples and cultures. Old crafts, as a reflection of traditional knowledge, have an extremely important role in portraying intangible and material cultural wealth of a people. Likewise, in the past, through the exchange and 
circulation of craft products they contributed to the cultural and civilizational interaction and linkages between nations.

'European Heritage Days' have been taken place in Europe for 23 years, and cultural institutions of Serbia through various cultural events have taken part in the program for 13 years. At this event people represent the heritage as a common heritage of the peoples of Europe, the diversity of cultures, traditions and customs. Ministry of Culture and Information of the Republic of Serbia, as a program coordinator chose the theme 'Old and traditional crafts - the preservation and maintenance' for 2015. That is why Friends of the Children of Belgrade and the Children's Cultural Centre of Belgrade organized an exhibition of works of traditional crafts created in the educational and creative workshops for children and young people of Belgrade. The exhibition presents about 60 exhibits (icons, calligraphy, oil paintings, prints, macramé, hand weaving items, objects weaved in smyrna technique, leather objects, mosaics, fresco paintings and masks). During the opening of the exhibition it was organized practical work of children and young people in the calligraphic writing technique. On the occasion of this event it was held a round table (Beoinfo, 2015). The importance of traditional crafts is reflected in the fact that at the round table sat representatives of the ministries of economy, culture and information, trade, tourism and telecommunications, tourism organizations, cultural centers and others.

'European Heritage Days' have been taken place in other parts of Serbia as well (Map 1). Media covered the following events. The cultural institutions of Mladenovac organized exhibitions, lectures and workshops. Museum of Pirot also joined the campaign. On the subject of 'Old and traditional crafts - the preservation and maintenance', the Open air museum 'Staro selo' in Sirogojno organized the fifth Fair of traditional crafts and professions. At the fair, people presented artisanal products, and their use value, as well as traditional techniques and skills of making of products and on this occasion the visitors to the Museum could participate actively. The exhibition 'Zlatne ruke zanatske' was dedicated to craftsmen who still nurture the skills of handmade craft products. In Nis on the same occasion, the Institute for Protection of Monuments arranged artistic photography exhibition at the Gallery of NKC 'Old crafts - Intangible Cultural Heritage Lužnice', which displays portraits of last furriers, quilt makers, farriers and other crafts of Babušnica. Contribution of the Museum of Novi Pazar had a form of photo exhibitions and film screenings on the theme 'Old and traditional crafts, conservation and maintenance'. The Department of Ethnology of National Museum in Čačak had an exhibit and fair of traditional crafts called 'Zanat zlata vredan'. It showed the great ethnological collection, i.e. numerous objects, documents and photographs related to the craft history of this town. They presented the handicraft workshops (cobbler, shoemaker, draper, carpenter and cooper) as well as guild letters, and everything that used to be taken to pass the master's exam. Students of the Art School in Čačak showed their skills in wood carving and stone masonry. Besides them, the Fair was attended by organizations and individuals engaged in production and processing of various handicrafts applying old techniques and technology.

General Association of Entrepreneurs of the Municipality of Kovin organized training for making objects of bulrush and work on a loom, in order to preserve it or as an opportunity for the unemployed and sufficient basis for starting an independent business. There was a great response and interest in the training.

Project 'Exploring inspirations' presented the results in the general exhibition in the Great gallery of KC Grad. This project engaged designers of clothing, shoes and jewelry from the Netherlands and Serbia with the aim to, inspired by old crafts and techniques, implement their own contemporary designer pieces that will be produced using traditional techniques such as knitting, embroidery, filigree and other (Cvetković, 2015).

Events related to traditional crafts have been organized outside the borders of Serbia as well. Producers of honey, cobblers, blacksmiths, mat makers, people who make wicker baskets, confectioners (members of the association 'Sweet smile' and 'Dream house'), objects of wood and other utilities, as well as painters from Jagodina and the Morava region exhibited in Paralia, Greece. Based on realized turnover, they came to the conclusion that the old crafts in Jagodina have a future.

In Serbia there are also other events on the subject of traditional crafts. For example, the Ethno festival 'Banat story' was held in 2013 in Zrenjanin settlement, Bagljaš, organized by the 
local community 'Veljko Vlahović', Association of Citizens 'Association for development Bagljaš' and Association 'Sunflower'. Financial support was received from the company 'Gomex'.

Within Negotin summer in the city park was open Mini Fair of souvenirs. Program of Tourist organization called 'Square of old crafts' included an interactive workshop which was organized in cooperation with Association 'Our hands' within the project 'Travelling craftsmen'. There were shown ways of making traditional crafts such as footwear making, embroidery, weaving on a loom, calligraphy and others. Visitors themselves could participate in making.

Summer school of traditional crafts and conservation has been held for several years in Archeo-ethno Park in Ravna and organized by the Homeland museum of Knjaževac and the Central Institute for Conservation in Belgrade with the support of the Ministry of Culture and Information of the Republic of Serbia (Best, 2015).

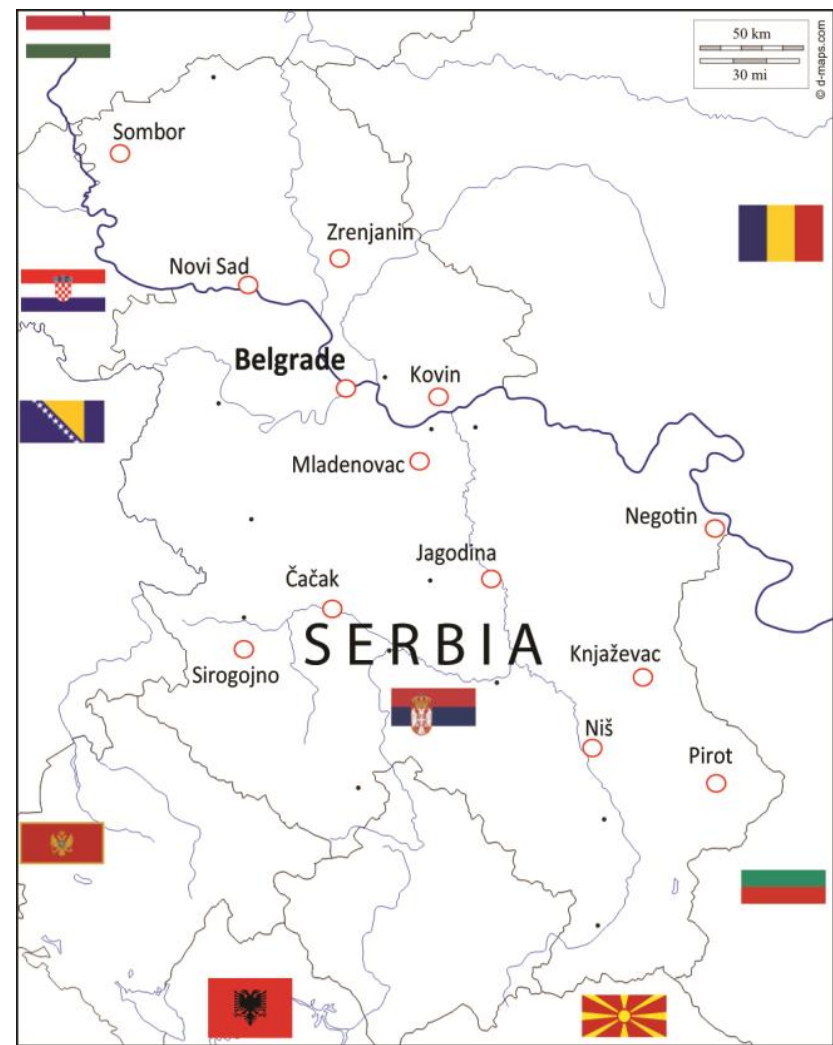

Map Geographic position of settlements which over the past years have organized events related to traditional crafts, Source: Authors

In the permanent exhibition of the Ethnology Department of the National Museum of Zrenjanin, it is presented the life of the four nations (Serbs, Hungarians, Slovaks and Romanians) in the rural interior, through costumes, industry and old crafts of Central Banat from the late $19^{\text {th }}$ and early $2 \mathrm{O}^{\text {th }}$ century. Part of the permanent exhibition of traditional occupations includes two units. The first unit presents written documents - letters, diplomas, ribbon indicating the active participation of artisans in the life of the city. Businessmen formed their own associations and participated in humanitarian work helping the socially vulnerable fellow citizens and students. The second segment exposes tools and products used in footwear and furrier workshops. Traditional crafts have left a significant mark in history, which are witnesses of the level of economic development. Ethnology part of the permanent exhibition of the National Museum of Zrenjanin organizes workshops entitled 'Once upon a time there were Goldsmith girl and Furrier boy...' for children of the fourth and fifth graders. Children after story on traditional crafts (with special emphasis on the production and decoration of clothing in the past) draw and reflect ornament (decoration for clothing). Participation in the workshops is free, working material is provided by museum. 
Problems of traditional crafts

Traditional craftsmen in Serbia face a series of problems. Talking to them revealed the following facts. Products of craftsmanship are frequently uncompetitive on the market. The production process is long, and prices must be affordable. Only top quality may be a reason for a higher price. However, it is important and how the purchasing power of potential customers.

Most people (70.1\%) who are engaged in traditional crafts say that it is sustainable only if it is practiced individually. By engaging employees taxes and duties make crafts unsustainable. When raw materials do not have a certificate of origin, then their placement in the international market is difficult. Rents for shops are very high therefore it is not profitable for traditional craftsmen to open their own stores. Some (31.0 \%) reported that they would appreciate if they got beneficial price of renting. For example, tailors say they threatened by the goods sold by the Chinese and second hand shops. Therefore, they are mainly engaged in repairs. Sewing new clothes is order by those who keep to themselves, or they are out of standards. Prices are adapted to general poverty, and the visit is small. Shoemakers rarely make new products, but have customers due to the low quality of industrial footwear. According to Dugalic (2009), the greatest chance to survive have candy makers, potters and waxers, because the industry does not produce, for example, candles for baptism. However, nobody has data exactly how many craft shops in Serbia still exist. It is quite certain that those who still survive, do not export their products and struggle to sell them. Studies have shown that traditional crafts are disappearing today mainly because of the lack of market for their products. Accordingly, Čomić (2003) and Ivkov-Džigurski et al (2008) have written about souvenirs. Tourist demand for souvenirs and their uncritical desire for objects that have local character are frequently cited as reasons for the decline of cultural and artistic standards. Craftsmen change shape and method of making products to fit the tastes of tourists. The demand of tourists for cheap, exotic, permanent souvenirs influenced the change and adaptation of traditional art forms.

\section{Associations and individuals}

In this historical moment, looking at the number and geo-demographic characteristics of those who are engaged in traditional crafts is a big problem, but there are also positive examples. In Novi Sad, there are about 25 undertakings whose products are considered as products of old and artistic crafts and traditional handicrafts. They are mostly in the following settlements: Novi Sad, Petrovaradin, Kać and Sremska Kamenica. These are products such as handmade jewelry made with precious metals, hand-made parts for watches and clocks, then hand-woven products, coppersmith products, artistic treated bandages, hand-embroidered copies of icons and emblems and others, which are produced in the traditional way, manually or mainly manually (Novi Sad, 2013). One of the numerous associations is 'Ethno Network' from Belgrade, which includes approximately 400 women engaged in traditional crafts. Than, members of the association that deals with the preservation of traditional crafts from Jagodina 'Ethno-forma' believe that through old crafts they combine nice and useful by making national costumes, floor cloth, rugs, and all traditional products.

However, the more common are examples of individuals such as Slaviša Ivanovic from the village Dražmirovac at Jagodina who for 30 years has continued the family tradition of their ancestors back over a hundred years and successfully produces and sells Serbian folk costumes and Serbian peasant shoes. Old man Milan Jovanovic from the village Lovci, near to Jagodina, is selftaught and has worked as farrier, wheelwright and carpenter, then as carver, produces rifles, building things. Živorad Stanković from Malo Lanište as a 13 year old boy has continued the family tradition and is engaged in wickerwork. He is ill because of trampling in the water up to his chest for removing reeds for matting. One of the few people who work as a cooper is Mirko Kovačić (70) from the village of Sirogojno near Zlatibor. He started to do this job as a 15 year old boy, and the same job performed his father and grandfather. In Zrenjanin there are Zoran Slijepčević, owner of the craft shop for making hand-woven items and Pavle Nećakov whose shop makes matting products etc.

Opinions of people who are engaged in traditional crafts are divided on the issue of association. Some who are engaged in traditional crafts do not mind the individuality (42.5\%) and that they are the only ones or a small number of people is engaged in their type of craft, because with increasing competition they would sell smaller number of products. Still others tend to 
network (54.0 \%), because they are thus recognizable and competitive, both in domestic and international markets.

Product placement

In addition to the unfavorable legal regulations, fiscal policy and economic conditions for the restoration of traditional crafts in Serbia, the products of talented individuals or master workshops find their way to customers. Product placement is in shops of unique products, at trade fairs, through social networks and personal contacts. In Belgrade, the products of traditional craftsmanship can be found in three retail shops, which are located in Brankova Street, Belgrade Palace and Nikola Tesla Airport. Research showed that well-known companies, such as 'Telekom Serbia', 'Delta Generali Insurance', 'Holcim', 'Tiger', buy products of traditional crafts as gifts for their business partners. For placement of the traditional crafts, great importance has adequacy of location. This should be kept in mind, if we know that our traditional crafts impress foreigners. Accordingly, besides the airport, people who are engaged in traditional craftsmanship (89.7\%) believe that it would be appropriate to form sales checkpoints at border crossings, along highways and large moorings for tourists who sail the Danube.

\section{Conclusion}

Analysis of traditional crafts from the geographical point of view has shown that in terms of the natural predispositions in Serbia there is a good raw material base. Geo-demographic characteristics of people who are engaged in traditional crafts can be indirectly learned from the available literature and texts, but extensive research would give a more precise picture. Since the products of traditional crafts are mostly sold at various events, these manifestations could be places where we could find answers about geo-demographic characteristics of craftsmen, and all other matters related to their characteristics. The results showed that investigative journalism i.e. written evidence in electronic media or TV reports and shows are excellent sources of information on the status of traditional crafts in the 21st century in Serbia. However, they also usually monitor events or individuals. The paper showed that the political support is very important for conservation, and thus the sustainability of traditional crafts.

Examples from the world point to the existence of other opportunities provided by traditional crafts, which are not practiced in our country, such as medical rehabilitation. In support of sustainability goes implementation of studying and practicing some of the traditional crafts within educational or extra-curricular activities of pupils and students. Raising awareness on the benefits of conservation through organized actions of demonstrations of traditional crafts among young people may contribute to initiating and developing their activation in the local environment, whether in the form of volunteering or entrepreneurial initiatives. Efforts in the marketing of traditional crafts could motivate greater activation of the unemployed, particularly women with the intention of self-employment.

\section{References:}

1. Sl. glasnik RS [2012]. Pravilnik o određivanju poslova koji se smatraju starim i umetničkim zanatima, odnosno poslovima domaće radinosti, načinu sertifikovanja istih i vođenju posebne evidencije izdatih sertifikata, Službeni glasnik Republike Srbije, br. 56/2012, Ministarstvo ekonomije I regionalnog razvoja, Republika Srbija http://www.overa.rs/pravilnik-o-odredivanjuposlova-koji-se-smatraju-starim-i-umetnickim-zanatima-odnosno-poslovima-domace-radinostinacinu-sertifikovanja-istih-i-vodenju-posebne-evidencije-izdatih-sertifikata.html

2. e-Kapija [2013]. Država pomaže tradicionalne rukotvorine, Šumadija press, Kragujevac http://sumadijapress.co.rs/drzava-pomaze-tradicionalne-rukotvorine/

3. Patton, M. Q. [1990]. Qualitative evaluation and research methods . SAGE Publications, inc.

4. Miljković Katić, B. [2013]. Seosko profesionalno zanatstvo Kneževine Srbije (1834-1866). Istorijski časopis, (62), 309-329.

5. Dušković, V. [2009]. Stari zanati u Srbiji.

6. Staniland, K. [1991]. Embroiderers. University of Toronto Press. 
7. Bilgin, M. H., Demir, E., Lau, M. C. K., Kin-Man To, C., \& Zhang, Z. M. [2011]. The Turkish handmade carpet industry: an analysis in comparison with select Asian countries. Journal of the Textile Institute, 102(6), 514-526.

8. Jevremović, G. [2011]. Working Through Tradition: Rug Farming In Anatolia. The Individual and Tradition: Folkloristic Perspectives, (8), 441.

9. Dhupelia-Mesthrie, U. [2012]. Gujarati shoemakers in twentieth-century Cape Town: Family, gender, caste and community. Journal of Southern African Studies, 38(1), 167-182.

10. Sezeva, N. I. [2013]. Traditional Folk Art Crafts in the Culture of Contemporary Russia: Tyumen People's Carpet (XVIII-BEG. XXI Centuries). Middle-East Journal of Scientific Research, 16(8), 1100-1104.

11. Clark, A. C. R. [2013]. The Handmade Artists'book: Space, Materiality, And the Dynamics of Communication in Book Arts (Doctoral dissertation, The University of Alabama TUSCALOOSA).

12. Petkovski, D. [1992]. Ulici vo Skopje so iminja na stari, retki i izumreni zanati. Etnologspisanie na združenieto na etnolozite na makedonija, (2), 127-141.

13. Pal, T. [2011]. Geography of Urban Cobblers (Muchi or Shoemaker): An Over-view in Bolpur Town, West Bengal, India. International Journal of Business and Social Science, 2 (3), 238, 245 .

14. Chamorro, I. [2007]. Consideraciones sobre el libro: Artesanías y cooperación en América Latina y el Caribe. Artesanías de América, 63-64, 263-282.

15. Giordano, B. D. [2007]. The crafts of Cuenca in the contemporary world. Crafts America, 65, 25-40.

16. Hailwood, M. [2011]. Sociability, work and labouring identity in seventeenth-century England. Cultural and Social History, 8(1), 9-29.

17. Dean, T. J., Brown, R. L., \& Stango, V. [20oo]. Environmental regulation as a barrier to the formation of small manufacturing establishments: A longitudinal examination. Journal of Environmental Economics and Management, 40, 56-75.

18. Sánchez-Medina, P. S., Domínguez, M. L., \& Hernández, J. P. [2010]. Gender and environmental behaviour of clay crafts business. Gestión y Política Pública, XIX(1), 79-11O.

19. Colombini, D., Occhipinti, E., Peluso, R., \& Montomoli, L. [2012]. Hazard identification and pre-map with a simple specific tool: synthesis of application experience in handicrafts in various productive sectors. Work-Journal of Prevention Assessment and Rehabilitation, 41, 3956.

20. Đurković, M. [2011]. Однос културне политике према народној култури у Србији. Sociološki pregled, Vol. XLV (IX-XII), no. 4 561-574.

21. Nason, J. D. [1984]. Tourism, handicrafts, and ethnic identity in Micronesia. Annals of tourism research, 11(3), 421-449.

22. Zhiyi, Z. H. U. [2014]. Legal Protection of the Cultures of Ethnic Minorities in China. Cross-Cultural Communication, 10(1), 21-26.

23. Coates, R. I., Aguirre, A., \& Campos-Villanueva, Á. [2015]. Plant Use by Artisans Within the Los Tuxtlas Biosphere Reserve, Southern Mexico. Human Ecology, 43(4), 621-631.

24. Little, W. E. [2014]. Performing tourism: Maya women's strategies. Signs, 4O(1).

25. Sánchez-Medina, P. S., Díaz-Pichardo, R., Bautista-Cruz, A., \& Toledo-López, A. [2015]. Environmental compliance and economic and environmental performance: Evidence from handicrafts small businesses in Mexico. Journal of Business Ethics, 126(3), 381-393.

26. Mustafa, M. [2011]. Potential of Sustaining Handicrafts as a Tourism Product in Jordan. International Journal of Business and Social Science, 2(2), 145-152.

27. Avais, M. A., Wassan, A. A., \& Erum, M. [2014]. Socio-Economic Causes of Child labor in Carpet Weaving Industry: A Case Study of Union Council Ali Wahan. Journal of Social Welfare and Human Rights, 2(1), 251-264.

28. Mir, L. A., \& Bhushan, S. [2014]. An Analysis of Current Scenario and Contribution of Handicrafts in Indian Economy. Journal of Economics and Sustainable Development, 5(9), 75-78.

29. Holder, J. [1989]. Tourism and the future of Caribbean handicraft. Tourism management, $10(4), 310-314$.

30. Parnwell, M. J., Hitchcock, M., \& King, V. T. [1993]. Tourism and rural handicrafts in Thailand. Tourism in South-East Asia., 234-257. 
31. Christie, I., \& Cromption, D. E. [2001]. Tourism in Africa. World Bank. (C) World Bank. https://www.openknowledge.worldbank.org/handle/10986/9804 License: CC BY 3.o Unported.

32. Kiran, J. N., Prasad, V. L., Kavya, C., \& Nagaraja, G. N. [2014]. Investment opportunities in agri-tourism in India. International Journal of Commerce and Business Management, 7(2), 400-405.

33. Dutton, R. W. [1983]. Handicrafts in Oman and their role in rural community development. Geoforum, 14(3), 341-352.

34. Karami, M., Choobchian, S., \& Kalantari, K. [2013]. Site selection for Handy Craft Market in South Khorasan Province Using Analytical Hierarchy Process (AHP). Journal of UrbanRegional Studies and Research, 4(15), 21-36.

35. HZZZ [2011] Osnaživanje i aktiviranje žena na tržištu rada. Program IPA IV Razvoj ljudskih potencijala Projekt „Žene na tržištu rada“. Hrvatski zavod za zapošljavanje, Područna služba Osijek, Osijek

36. Cogollor, J. M., Hughes, C., Ferre, M., Rojo, J., Hermsdörfer, J., Wing, A., \& Campo, S. [2012]. Handmade task tracking applied to cognitive rehabilitation. Sensors, 12(10), 14214-14231.

37. Novaković, K. [2004]. Odlike narodnog veza u Vojvodini. Etnologija. Rad Muzeja Vojvodine 46. 151-184.

38. Šestan, I. [2006]. Tradicijski zanati O problemima etnološkog definiranja «jasnog pojma». Etnološka istraživanja, (11), 111-121.

39. Hadžić, O. [2005]. Kulturni turizam. Novi Sad: Univerzitet u Novom Sadu, Prirodnomatematički fakultet, Departman za geografiju, turizam i hotelijerstvo.

40. Krstović, N. [2012]. Занати: где после музеја? Економузеји: изазов музејима (на отвореном) или „нова реалност “у очувању културног наслеђа. Гласник Етнографског института СAHУ, (Vol. 60/1), 79-92.

41. RTS [2011]. Poslednji skeledžija na Ibru http://www.rts.rs/

42. Gucijan S. [2009]. Živana, poslednji skeledžija na Drini. Politika. http://www.politika.rs/rubrike/Drustvo/Zivana-poslednji-skeledzija-na-Drini.sr.html

43. Apostolovski, A. [2012]. Poslednji skeledžija na Savi, Politika, ttp://www.politika.rs/rubrike/Drustvo/Poslednji-skeledzija-na-Savi.sr.html (4):1

44. Dhamija, J. [1981]. Women and handicrafts: myth and reality. Seeds (New York, NY),

45. McLeod, E. E. [1999]. In good hands: The women of the Canadian Handicrafts Guild (Vol. 10). McGill-Queen's Press-MQUP.

46. Rostami Povey, E. [2003]. Women in Afghanistan: Passive victims of the borga or active social participants? Development in Practice, 13(2-3), 266-277.

47. Cvetković, M. [2015]. Očuvanje tradicionalnih zanata projektom Exploring inspirations, Plezir, http://plezirmagazin.net/tag/tradicionalni-zanati/

48. Čomić, Đ. [2003]. Sociologija turizma. Beograd: Viša hotelijerska škola.

49. Erić, D., Behara, I., Đuričin, S., Kecman, N., Jakišić, B. [2012]. Finansiranje malih i srednjih preduzeća u Srbiji, Institut ekonomskih nauka, Beograd

50. Dugalić, V. [2009]. Zanati koji nestaju. Politika. Beograd http://www.politika.rs/rubrike/Drustvo/Zanati-koji-nestaju.sr.html

51. Best [2015]. Otvaranje letnje škole tradicionalnih zanata danas u Arheo etno parku u Ravni, tvbest http://www.tvbest.rs/tag/108954

52. Ivkov-Džigurski, A., Kovačević, T., \& Zakić, L. [2008]. Souvenirs as a part of cultural heritage of population in function of tourist product. Glasnik srpskog geografskog drustva, 88(4), 59-69.

53. Novi Sad [2013]. Pasaž starih zanata dobio prve stanare, Zvanična prezentacija Grada Novog Sada, http://www.novisad.rs/lat/pasaz-starih-zanata-dobio-prve-stanare

54. Beoinfo [2015]. Održan okrugli sto „Stari i tradicionalni zanati - čuvanje i održanje”, Beoinfo vesti, Beograd http://www.beograd.rs/cms/view.php?id=1703963 
УДК 79

\title{
Географические аспекты традиционных ремесел в Сербии
}

\author{
${ }^{1}$ Тамара Лукич \\ 2 Татьяна Стоянович \\ 3 Боян Деркан \\ ${ }_{4}^{4}$ Милка Бубало Живкович \\ 5 Елена Живкович
}

\author{
${ }^{1}$ Университет Нови-Сад, факультет наук, Нови-Сад, Сербия \\ Доцент \\ Корреспондирующий автор \\ E-mail: snstamara@yahoo.com \\ ${ }^{2}$ Veljko Petrović' High School, Сомбop, Сербия \\ Кандидат наук \\ 3 Университет Нови-Сад, факультет наук, Нови-Сад, Сербия \\ Доцент \\ 4 Университет Нови-Сад, факультет наук, Нови-Сад, Сербия \\ Доцент \\ 5 University of Nis, Faculty of Science and Mathematics, Сербия \\ Доцент
}

Аннотация. Первая часть работы посвящена современным исследованиям в области традиционных ремесел в мире. Затем, традиционные ремесла рассматривается с географической точки зрения. В статье анализируется взаимосвязь между физикогеографическими характеристиками, типом ремесленного производства и сырьевой базы. Большая часть исследования посвящена социальным факторам, которые оказывают влияние на традиционные ремесла. В статье перечислены формы поддержки для сохранения традиционных ремесел. В статье приведены примеры работы по сохранению традиционных ремесел в Сербии. Также описаны возможности размещения предметов, произведенных по традиционным ремеслам. Путем отображения проявлений, в работе показаны некоторые традиционные ремесла. Кроме того, в статье обсуждаются актуальные проблемы развития традиционных ремесел. Значимость статьи заключается в том, что она подготовлена по записям о традиционных ремеслах в Сербии в начале 21-го века, потому что они больше не являются предметом мониторинга официальных статистических данных.

Ключевые слова: рукоделие, традиции, Сербия, проявления, устойчивость. 